\title{
Balancing Energy Development and Environmental Rights: From Foreign Litigation to International Insurance?
}

\author{
Emeka Duruigbo*
}

DOI: $10.21827 / 5 \mathrm{a} 86 \mathrm{a} 7 \mathrm{~d} 32 \mathrm{f} 1 \mathrm{f0}$

\section{Keywords}

ENVIRONMENTAL InSURANCE; FOREIGN DIRECT LIABILITY; CORPORATE AcCountability; ENERgy Security; Human Rights; OIL POllution; Multinationals; Shell Petroleum; MigA.

\begin{abstract}
This article examines the use of foreign direct liability suits, including the ones currently in the Dutch court system by Nigerian plaintiffs against Shell Petroleum, to protect environmental and economic interests in oil-producing communities. The paper suggests that while these suits are a valuable tool in advancing the cause of a clean environment, they fall short in accomplishing the goal. Additional tools, such as an international insurance scheme, may need to be introduced to create a more effective framework.
\end{abstract}

\section{Introduction}

Over the years, victims of human rights and environmental abuse emanating from the operations of multinational corporations in developing countries have sought remedies in the domestic courts of the United States and, more recently, some European countries. They have relied on the Alien Tort Statute (ATS) and traditional tort theories such as negligence, strict liability, trespass and nuisance. These efforts have met with minimal success. Worse still, the doors seem to be closing fast in the case of using the United States as an avenue for redress, in light of the Supreme Court decision in Kiobel v. Royal Dutch Shell. ${ }^{1}$ Nevertheless, tort claims are likely to continue in Europe and the United

Professor of Law, Thurgood Marshall School of Law, Texas Southern University. I am grateful for the able research assistance of Adenike Adesokan (JD 2014).

1 Kiobel v. Royal Dutch Petroleum Co., 133 S. Ct. 1659, 185 L. Ed. 2d 671, 2013. For useful commentary on the decision, see Meyer, J. A., "Extraterritorial Common Law: Does The Common Law Apply Abroad?", Georgetown Law Journal, vol. 102, 2014, 301-350, 305. ('In the meantime, the Supreme Court has recently ruled in Kiobel v. Royal Dutch Petroleum Co. to apply the statutory presumption against extraterritoriality to severely curtail the extraterritorial application of the Alien Tort Statute (ATS)--a federal statute that to date has served as the primary vehicle for scores of lawsuits in the U.S. courts arising from human rights violations in foreign countries.') (citation omitted); Slawotsky, J., "ATS Liability For Rogue Banking In A Post-Kiobel World", Hastings International and Comparative Law Review, vol. 37, 2014, 121-158, 122. 'In Kiobel v. Royal Dutch Petroleum Co., [FN1] the Supreme Court dramatically limited the viability of utilising the Alien Tort Statute ("ATS") to enforce international law norms. In Kiobel, a five-justice majority of the Supreme Court held that a presumption exists against extraterritorial application of the ATS. However, the majority opinion ruled the presumption can be 
States, with the venue of litigation in the latter possibly shifting more toward state courts, as opposed to federal courts under the ATS. ${ }^{2}$ This paper introduces compulsory international insurance as another tool for preventing significant environmental harm and human rights abuse, protecting local communities hosting major energy projects and generally ensuring the wellbeing of the residents of these communities.

The importance of tort liability as a tool for seeking legal redress and regulating behaviour cannot be over-emphasised. Nevertheless, to accomplish some of the goals of tort liability, including financial redress for victims and prevention of damaging behaviour through the deterrence effect of financial liability, it is important to complement this tool with other tools. One proven tool that can serve this purpose is liability insurance that provides a guaranteed source of compensation to victims and enables them to bring direct action against the insurers. In that regard, one can draw lessons from pollution of international and territorial waters through oil spills from ships and related vessels. For many years, victims of ship-source oil pollution relied on tort remedies by bringing claims based on negligence, nuisance, trespass and strict liability. ${ }^{3}$ However, following the Torrey Canyon disaster of 1967, the international community formulated rules and established structures for compensating environmental pollution victims while deterring environmentally damaging behaviour by oil companies and ship owners. ${ }^{4}$ A similar system, mutatis mutandis, should be contemplated for catastrophic oil spills not involving ships or structures covered under the existing international conventions. ${ }^{5}$

To put this issue in the proper context, victims of the Deep Water Horizon incident of 2010 in the United States, which ranks as the largest oil spill in the history of the world, ${ }^{6}$ may not be able to rely on these conventions to seek redress. ${ }^{7}$ Similarly, victims of business-associated human rights violations and massive oil spills that have devastated the environment in the Niger Delta area of Nigeria are not afforded meaningful remedies under international law. As the United Nations, in particular the Human Rights Council, considers ways of regulating corporate behaviour, it should include as part of the

rebutted if the international law violation 'touches and concerns' the United States with 'sufficient force' (citations omitted).

2 Whytock, C. A. et al., "Foreword: After Kiobel: International Human Rights Litigation in State Courts and Under State Law", UC Irvine Law Review, vol. 3, ed. 1, 2013, 1-8, 5, stating that, after Kiobel, 'plaintiffs alleging human rights violations are increasingly likely to consider pursuing their claims in state courts or under state law'.

3 Billah, M. M., "The Role of Insurance in Providing Adequate Compensation and in Reducing Pollution Incidents: the Case of the International Oil Pollution Liability Regime", Pace Environmental Law Review, vol. 29, 2011, 42-78, 45.

4 Nordtvedt Reeve, L. L., "Of Whales and Ships: Impacts on the Great Whales of Underwater Noise Pollution From Commercial Shipping and Proposals for Regulation Under International Law", Ocean and Coastal Law Journal, vol. 18, 2012, 127-166, 141: '[t] he need for regulation became alarmingly clear when, on March 18, 1967, the supertanker Torrey Canyon ran aground in the waters of the U.K. and began to discharge oil into the sea off the Cornish coast.' (citation omitted).

5 The international oil pollution compensation regime is comprised of two international conventions: (1) International Convention on Civil Liability for Oil Pollution Damage, 1969, 973 UNTS 3; and (2) International Convention on the Establishment of an International Fund for Compensation for Oil Pollution Damage, 1971, 1110 UNTS 57 and amendments thereto.

6 Smith, M., "The Deepwater Horizon Disaster: An Examination of the Spill's Impact on the Gap in International Regulation of Oil Pollution from Fixed Platforms", Emory International Law Review, vol. 25. 2011, 1477-1516, 1477.

7 Id., $1488,1505$. 
regulatory kit, the imposition of compulsory insurance for risks faced by host communities from business-related human rights abuses and environmental devastation. The insurance regime would include a provision that ensures that victims of the human rights abuse and environmental damage have access to the insurance proceeds by enabling them to bring direct action against the insurers. An anticipated secondary consequence of the proposal is improvement of corporate-community-government relations that affords the social license that corporations need for successful operations in the host areas. ${ }^{8}$ Ultimately, this approach is consistent with the notion of sustainable development in its classic formulation that seeks to balance economic growth with environmental protection. ${ }^{9}$

The article is organised into five parts. Part I focuses on the concept of foreign direct liability ("FDL"), paying particular attention to its rationale. FDL suits are premised on the notion that the companies that benefit from foreign direct investment should also bear the burden of compensating for the negative consequences of their business operations, whether such results occur directly through their acts or omissions or as a result of the action or inaction of their subsidiaries. ${ }^{10}$ In other words, FDL proponents view foreign direct liability as the flip side of foreign direct investment. ${ }^{11}$ Part II discusses recent international cases on foreign direct liability, namely the cases in the Dutch court system by Nigerian plaintiffs against the international oil company, Shell. Part III considers the value of using insurance as a tool for redressing environmental damage and argues for the inclusion of a mandatory insurance provision in a proposed international human rights treaty that aims to impose obligations on corporations. Part IV examines some potential objections to the insurance proposal. Part V is the conclusion.

\section{Foreign Direct Investment Versus Foreign Direct Liability}

\section{II.1 Foreign Direct Investment}

There are two primary sources of foreign investment into any country, namely foreign portfolio investment ("FPI") and foreign direct investment ("FDI"). Portfolio investment refers to the kind of investment that does not involve building a business and the accompanying infrastructure; instead it takes the form of investing through the stock market. ${ }^{12}$ Foreign direct investment, usually involves establishing of a physical presence

8 For a development of the social license argument in international operations, see Duruigbo, E., "Community Equity Participation in African Petroleum Ventures: Path to Economic Growth?" North Carolina Central Law Review, vol. 35, 2013, 111.

9 UN World Commission on Environment and Development, Bruntland, G., REPORT: Our Common Future: Report of the World Commission on Environment and Development, UN Doc. A/42/427, 1987, Switzerland, defining sustainable development as 'development that meets the needs of the present without compromising the ability of future generations to meet their own needs'.

10 It is an inveterate principle that those who reap the burden should bear the burden, and vice versa, as encapsulated in the maxim qui sentit commodum sentire debet et onus et contra. For a sample of cases applying the principle, see Tillman v. Commercial Credit Loans, Inc., 362 N.C. 93, 115; 655 S.E.2d 362, 2008; Norfleet v. Cromwell, 70 N.C. 510, 516, 70 N.C. 634, 641, 1874.

11 See infra Part I.

12 Buzzle, Sukumar, S., Difference Between Foreign Direct Investment and Foreign Portfolio Investment, 8 November 2011, available online at <www.buzzle.com/articles/difference-between-foreign-directinvestment-and-foreign-portfolio-investment.html> (accessed 26 February 2014), defining foreign 
in the country. ${ }^{13}$ Put in clearer terms, 'FDI is a direct investment in buildings, technologies, equipment and machinery belonging to the firm of a host country (foreign firm), while FPI is an indirect investment in the foreign firm by simply buying the stocks of the company and not getting involved in any major activities of the firm.' ${ }^{14}$ Accordingly, FDI also tends to involve a longer investment horizon "wherein the investor reflects a long-lasting and controlling interest in the firm, while FPI is a shortterm process" with the portfolio investor evincing little or no interest in managing or controlling the firm, considering that such investor has a short-term investment plan. ${ }^{15}$

The past few decades have witnessed a tremendous growth in foreign direct investment, leading to the presence in the global economic stage today of tens of thousands of multinational corporations and their subsidiaries with operations in various corners of the world. ${ }^{16}$ Support for increased FDI partly stems from the belief that FDI flows are beneficial to the recipient or host country, although critics note that the benefits are insufficient to justify the costs to these countries. ${ }^{17}$ Some scholars capture the conflicting sentiments by noting that corporations that invest in other countries afford benefits to the host countries in the form of the tax revenues they generate, jobs they create, skills and technologies they transfer and the contribution they make toward raising the standard of living in those countries. ${ }^{18}$

On the negative side of the ledger of contributions by foreign direct investors are the facts that these investors may orchestrate or be directly implicated in human rights abuse. In their quest for development through foreign investment and the attendant competition for investors, host countries may also lower their environmental and labor standards or

portfolio investment as 'a type of investment in financial securities such as bonds, debentures, stocks, warrants, options, domestic mutual funds, etc., with an intent to get financial gain.'.

13 According to the International Monetary Fund, FDI is 'an investment that is made to acquire a lasting interest in an enterprise operating in an economy other than that of the investor, the investor's purpose being to have an effective voice in the management of the enterprise' See Buzzle, Sukumar, S., Difference Between Foreign Direct Investment and Foreign Portfolio Investment, 8 November 2011, available online at $<$ www.buzzle.com/articles/difference-between-foreign-direct-investment-and-foreign-portfolio-

14 Ibid. investment.html> (accessed 26 February 2014).

15 Ibid.

16 UN GA, John Ruggie, REPORT: Report of the Special Representative of the Secretary-General on the issue of human rights and transnational corporations and other business enterprises 9 April 2010, UN Doc. $\mathrm{A} / \mathrm{HRC} / 14 / 27$, stating that there are more than eighty thousand multinational corporations operating in the world with about ten times the number of subsidiaries.

17 See Cragg, B. T., "Home is Where the Halt is: Mandating Corporate Social Responsibility Through Home State Regulation and Social Disclosure", Emory International Law Review, vol. 24, 2010, 735-775, 752-53; Anderson, R. J., "Toward Global Corporate Citizenship: Reframing Foreign Direct Investment Law", Michigan State Journal of International, vol. 18, 2009, 1-31, 3, stating that foreign direct investment has not always lived up to the expectation of providing such benefits as technology transfer, increased tax revenue and overall economic prosperity.

18 Wouters, J. and Chanet, L., "Corporate Human Rights Responsibility: A European Perspective", Northwestern Journal of International Human Rights, vol. 6, 2008, 262-303, 262; Bunn, I. D., "Global Advocacy for Corporate Accountability: Transatlantic Perspectives from the NGO Community", American University International Law Review, vol. 19, 2004, 1265-1306, 1269: '[a]lthough some NGOs have a distinctly "anti-corporate" stance, most readily acknowledge the potential benefits of corporate investment, including creating of jobs, improvement of infrastructure, and transfer of knowledge. The problem arises when corporate activities impinge on the realization of human rights, exploit workers, harm the environment, marginalize vulnerable populations, or produce other negative social consequences.' (citations omitted). 
adopt a lackadaisical attitude towards such issues, instead of enforcing existing rules, raising the bar and pushing for improvements. ${ }^{19}$ Thus, foreign investors are able to take advantage of these states of affairs, thereby unduly burdening these countries and further consigning them to the lower rungs of quality living. In order to avoid and redress the negative consequences of the involvement of multinational corporations, especially in developing countries, the phenomenon of foreign direct liability has emerged as the flip side of foreign direct investment. ${ }^{20}$

\section{II.2 Foreign Direct Liability}

Foreign direct liability refers to the concept of utilising claims brought by plaintiffs from developing countries seeking to hold the parents in a multinational corporate family, civilly liable in countries where the parents are headquartered, or in alternative jurisdictions, for their negligent decisions, actions or omissions that caused harm to the plaintiffs. ${ }^{21}$ In a useful description provided in the early 2000s, which has since become a little outmoded, Halina Ward views the term as denoting '[a] new wave of legal actions in the UK, US, Canada and Australia [that] aims to hold parent companies legally accountable in developed country courts for negative environmental, health and safety, labour or human rights impacts associated with the operations of members of their corporate family in developing countries. ${ }^{22}$ Ward further notes that these foreign direct liability suits seek to promote accountability 'by testing the boundaries of existing legal principles, rather than by calling for new regulation. ${ }^{23}$ Thus, in bringing these suits, a typical plaintiff relies on existing legal theories of negligence, nuisance and trespass,

19 Wouters, J., supra nt. 18, 262.

20 Ward, H., "Securing Transnational Corporate Accountability Through National Courts: Implications and Policy Options", Hastings International and Comparative Law Review, vol. 24, 2001, 451-474, 454. (stating that foreign direct liability cases 'represent the flip side of foreign direct investment. . . '); Afrin, Z., "Foreign Direct Investments and Sustainable Development in the Least-Developed Countries", Annual Survey of International and Comparative Law, vol. 10, 2004, 215-232, 231. ('The idea is to propose the flipside of foreign direct investment - foreign direct liability.'); Banakas, S., "A Global Concept of Justice - Dream or Nightmare? Looking at Different Concepts of Justice or Righteousness Competing in Today's World", Los Angeles Law Review, vol. 67, 2007, 1021-1042, 1038, quoting a statement by a senior executive of Google that global liability is following the footsteps of global commerce.

21 Thompson, R. C. et al., Translating Unocal: The Expanding Web of Liability for Business Entities Implicated in International Crimes, George Washington International Law Review, vol. 40, ed. 4, 2009, 841, 874: '[t] he concept of foreign direct liability has been applied in the context of civil lawsuits, where the parent itself, not the subsidiary, is alleged to have made decisions that have caused the harm.'; Enneking, L. F. H., "Crossing the Atlantic? The Political and Legal Feasibility of European Foreign Direct Liability Cases", George Washington International Law Review, vol. 40, ed. 4, 2009, 903, 904, referring to foreign direct liability cases as those cases 'in which plaintiffs file civil-liability claims against parent companies of multinational corporations in the courts of developed countries for damage caused by subsidiaries in developing countries...'.

22 Ward, H., "Governing Multinationals: The Role of Foreign Direct Liability", Royal Institute of International Affairs, vol. 18, ed. 1, 2001, available online at <chathamhouse.org/publications/papers/view/107528> (accessed 10 April 2014. Obviously, with the entrance or possible entrance of other countries, such as the Netherlands, a definition that is limited to a few enumerated countries may be considered incomplete or inaccurate.

23 Ibid. 
among others. ${ }^{24}$ Foreign direct liability 'defies the general principle that the jurisdiction of national courts is limited to national borders. It allows courts in one country to apply international laws or its own national laws "extraterritorially" to the operations of a corporate entity in another country. ${ }^{25}$ Indeed, scholars have identified different bases of parent company liability. ${ }^{26}$ These explanatory bases sometimes overlap or complement one another. ${ }^{27}$

Until recently, the United States has dominated the arena of foreign direct liability claims through litigation pursued under the Alien Tort Statute. ${ }^{28}$ Recent developments suggest that Europe may be emerging as the new theatre for seeking corporate liability and accountability for foreign infractions affecting the environment or human rights, or corporate actions that are simply characterised as torts against persons or property. ${ }^{29}$

Foreign direct liability litigation is premised on the notion that the nature and structure of the multinational corporations, with their global reach and influence, and the limitations of national jurisdiction over them, warrant the imposition of extraterritorial jurisdiction. ${ }^{30}$ Supported by the corporate law doctrines of separate legal personality and limited liability, with the attendant reluctance by the courts to pierce the corporate veil, parent companies are able to shield themselves from liability for the negative actions of their subsidiaries. ${ }^{31}$ The central objective of foreign direct liability suits, therefore, is to

24 Ramasastry, A., "Corporate Complicity: From Nuremberg to Rangoon: An Examination of Forced Labor Cases and Their Impact on the Liability of Multinational Corporations", Berkeley Journal of International Law, vol. 20, ed. 1, 2002, 91, 158, stating that foreign direct liability claims are based on 'a tort theory of a parent corporation's breach of duty through its investments overseas that may also create civil liability in the United States and potentially other jurisdictions.'; Enneking, L. F. H., supra nt. 21, 923, stating that 'foreign direct liability claims based on ordinary tort law are likely to involve complaints of negligent behavior by the multinational corporation's parent company, alleging that it owed individuals or communities in the host country a duty of care which it did not observe, resulting in personal, material, or environmental damage in that country.' (citation omitted).

25 Palmer, A., Community Redress and Multinational Enterprises, at 10 (Nov. 2003) available online at $<$ www.business-humanrights.org/Links/Repository/648189 $\geq$ (accessed 6 May 2014).

26 Mushkat, R., Corporate Social Responsibility, International Law, and Business Economics: Convergences and Divergences, Oregon Review of International Law, vol.12, ed. 1, 2010, 55, 64, discussing the various competing theories of parent company liability, including primary liability, vicarious liability, secondary liability and enterprise liability.

27 Id., 64.

28 Enneking, L. F. H., supra nt. 21, 904, noting that compared to the United States, foreign direct liability suits have been introduced more slowly in Europe; Banakas, supra nt. 20, 1038, quoting an observation that the U.S. tort litigation system was spreading to Europe. Cases brought under the Alien Tort Statute have also been described as a form of foreign direct liability litigation.

29 Kirshner, J. A., "Why is the U.S. Abdicating the Policing of Multinational Corporations to Europe?: Extraterritoriality, Sovereignty, and the Alien Tort Statute, Berkeley Journal of International Law", vol. 30, ed. 2, 2012, 259, 259-260: '[f]or several decades, the United States has acted as the global leader in imposing accountability on multinational corporations in the area of human rights. Recently, however, U.S. courts have declined jurisdiction to police their extraterritorial abuses[...].The retraction in willingness of U.S. courts to exercise extraterritorial jurisdiction over multinationals is occurring just as the courts of many European member states are becoming more open to it.'

30 Id., 264-268; Bunn, I. D., supra nt. 18, 1270: '[c]orporate structure and activities that transcend international boundaries are difficult to regulate.' (citation omitted).

31 Kirshner, J. A., supra nt. 29, 264-265; Muchlinski, P., "The Changing Face of Transnational Business Governance: Private Corporate Law Liability and Accountability of Transnational Groups in a PostFinancial Crisis World", Indiana Journal of Global Legal Studies, vol.18, ed. 2, 2011, 665, 685; Thompson, R. C., et al., supra nt. 21, 873-874: Laws that provide for 'piercing the corporate veil' so as to hold parents civilly or criminally accountable for the acts of a subsidiary, are found in multiple jurisdictions. 
seek to hold the parent companies to account in their home (or third) countries for activities that took place in host countries where the national political and judicial systems are unwilling or unable to do so for a variety of reasons. ${ }^{32}$ These lawsuits aim to impose pressure on "parent companies of multinational corporate groups to ensure that their behavior as direct investors in other countries matches the standard of care in the home country. ${ }^{33}$ Foreign direct liability is further justified by the fact that the host country's courts would often not have jurisdiction over the parent company. ${ }^{34}$ To the extent that the parent company's activities are legally sanctionable anywhere, not allowing such suits is tantamount to endorsing corporate impunity. ${ }^{35}$ Plaintiffs are also enamoured of foreign direct liability litigation because they expect larger verdicts than would be the case in their native countries. ${ }^{36}$ Foreign direct liability suits are further propelled by the presence of public interest lawyers that 'are employed by charitable organizations that receive support for their work from major foundations and see their work as part of broader efforts to strengthen the accountability of multinational corporate groups' and the existence of lawyers in for-profit law firms that undertake these cases on pro bono or contingency fee bases, thereby removing the financial burden on the plaintiffs. ${ }^{37}$

The future of foreign direct liability may be inexorably intertwined with an ability to carefully strike a balance between access to justice, which the exercise of extraterritorial jurisdiction affords, and the legitimate charges it generates about interference with the internal affairs of the host country and the need to avoid frictions in foreign relations. ${ }^{38}$

Even so, there also appears to be a deeply rooted respect for corporate forms, and courts apply the doctrine reluctantly. Some countries do not even recognise the doctrine too apply the doctrine in cases of crimes or torts. Where the doctrine applies, it generally requires that the parent must be proven to be the 'effective manager' of the subsidiary, or has 'imposed its own decisions,' that the corporate form is a 'mere façade,' or that 'the corporate identity was used to perpetrate a fraud.' Id. (citations omitted).

32 Kirshner, J. A., supra nt. 29, 266-267; Palmer, supra note 25, 10: '[p]eople and communities resorting to bringing claims in home-country courts are likely to have experienced obstacles to redress in the host jurisdiction.' For extensive discussions of reasons for seeking corporate accountability outside the host country of the multinational corporation, see Duruigbo, E., "Corporate Accountability and Liability for International Human Rights Abuses: Recent Changes and Recurring Challenges", Northwestern University Journal of International Human Rights, vol. 6, ed. 2, 2008, 222.

33 Bunn, I. D., supra nt. 18, 1293 (citation omitted); Ward, H., supra nt. 20, 456, stating that foreign direct liability suits share a close relationship with calls by NGOs for the alignment of behaviour of parent companies of multinational corporate groups as direct investors in other countries with applicable standards of care at home.

34 McLoughlin, A. M., "International Trend of Multinational Corporate Accountability for Human Rights Abuses and the Role of the United States", Ohio Northern University Law Review, vol. 33, ed. 1, 2007, 153, 158.

35 It bears noting that concern for lack of accountability of multinational corporations operating in developing countries has become a major point of reference in the negotiation of civil liability treaties. See Sachs, N., "Beyond the Liability Wall: Strengthening Tort Remedies in International Environmental Law”, UCLA Law Review, vol. 55, ed. 4, 2008, 837, 868.

36 See Ward, H., supra nt. 20, $462-464$.

37 Ibid.

38 See generally: Duruigbo, E., "Exhaustion of Local Remedies in Alien Tort Litigation: Implications for International Human Rights Protection", Fordham International Law Journal, vol. 29, ed. 6, 2006, 1245; Duruigbo, E., "The Economic Cost of Alien Tort Litigation: A Response to the Awakening Monster: The Alien Tort Statute of 1789", Minnesota Journal of Global Trade, vol. 14, ed. 1, 2004, 1.; Kirshner, J. A., supra nt. 29, 268; Ward, H., supra nt. 20, 459, stating that a 'major point of controversy is that because courts are public rather than private actors, foreign direct liability can generate foreign policy 
The new wave of foreign direct liability suits in Europe seem to be successfully navigating the murky waters through an innovative approach that seeks to avoid the obstacles occasioned by an application of the entity theory, which views the various units within the multinational corporate family as separate entities. ${ }^{39}$ Instead, plaintiffs emphasise the enterprise theory that characterises the units as members of one corporate family, and on that basis seek to hold the parents liable for their omissions in preventing the commission of the tort or perpetration of the environmental or human rights abuse. ${ }^{40}$ In other words, parent companies' actions are reviewed under the rules of the countries in which they reside, thus obviating or mellowing the objections to extraterritorial jurisdiction. ${ }^{41}$ It was apparently on the basis of this understanding that the Nigerian plaintiffs opted for litigation in the Netherlands against Royal Dutch Shell (RDS) and Shell Petroleum Development Company, Nigeria (SPDC). The following part provides a factual background of the Nigerian lawsuits.

\section{Recent Nigerian Cases in the Netherlands}

It is now well known that oil and gas production in Nigeria has had devastating consequences for the well-being of communities hosting the petroleum operations. ${ }^{42}$ These cases highlight the human and environmental toll that accompanies oil extraction and distribution in the resource-rich Niger Delta region of Nigeria.

\section{III.1 Factual Background}

The three cases focused on oil spills in the Nigerian states of Akwa Ibom, ${ }^{43}$ Rivers ${ }^{44}$ and Bayelsa, ${ }^{45}$ affecting the lands used for farming and fishing by the plaintiffs. The facts of the Goi oil spills in Rivers State are presented here for the purposes of illustration and illumination. On 27 April 2009, Mr. Barizaa Manson Tete Dooh, a resident of Goi in Rivers State of Nigeria in collaboration with Vereniging Milieudefensie (Friends of the

tensions.' Nevertheless, a persuasive case can be made for extraterritorial regulation or jurisdiction. See Broecker, C. "Better the Devil you Know: Home State Approaches to Transnational Corporate Accountability", New York University Journal of International Law and Policy, vol. 41, ed. 1, 2008, 159, 185-187, rationalising extraterritorial regulation on the grounds that it is current practice in some areas, host states are frequently unable or unwilling to protect human rights, and inability of actors besides States to thoroughly address short or medium-term violations of human rights by corporations.

39 McLoughlin, A. M., supra nt. 34, 170, outlining the distinction between the entity theory and enterprise theory approaches to corporate liability; see generally, Blumberg, P. I., "Accountability of MNCs: The Barriers Presented by Concepts of the Corporate Juridical Entity", Hastings International and Comparative Law Review, vol. 24, ed. 2, 2001, 297.

40 Kirshner, J. A., supra nt. 29, 279-281; Muchlinski, P., supra nt. 31, 685-86.

41 Ibid.

42 For extensive accounts, see e.g. Duruigbo, E., "Managing Oil Revenues for Socio-Economic Development in Nigeria: The Case for Community-Based Trust Funds", North Carolina Journal of International Law and Commercial Regulation, vol. 30, .2004-2005, 121-196;); Emeseh, E., et al., "Corporations, CSR and Self Regulation: What Lessons from the Global Financial Crisis?", German Law Journal, vol. 11, 2010, .230-259, 243-244 .

43 District Court of the Hague, 30 January 2013, Akpan v. Shell, C/09/337050 / HA ZA 09-1580.

44 District Court of the Hague, 30 January 2013, Dooh v. Shell, C/09/337058 / HA ZA 09-1581.

45 District Court of the Hague, 30 January 2013, Oguru v. Shell, C/09/330891/ HA ZA 09-0579. 
Earth Netherlands), brought the lawsuit against Royal Dutch Shell and Shell Petroleum Development Company (SPDC), Nigeria. ${ }^{46}$

The plaintiffs averred that on or around 23 August 2003, an oil spill occurred at a manifold - a set of high-pressure valves and associated piping that diverts oil or gas for a variety of purposes, such as disposal or storage, or to a production line - with the oil spilling into the Goi creek. Following the spill, the adjacent farmland and fish ponds owned or possessed by plaintiff Dooh were completely covered with oil. Two days later, plaintiff Dooh wrote a letter to SPDC, the operator of the manifold, notifying it of the spill and requesting an examination of the affected area and termination of the effects of the spill. SPDC did not respond to the letter or to a second letter sent shortly afterwards. Another spill occurred a year later, in October 2004, this time from the 24-inch BomuBonny Trans Niger oil pipeline (operated by SPDC) near Goi. The oil flowed into a creek next to the pipeline and spread across the first plaintiff's farmland and spilled into his fish ponds. SPDC responded two days after the discovery of the spill and embarked on efforts to clean up the contaminated site. However, the plaintiffs alleged that SPDC 'failed to adequately clean up both plaintiff Dooh's oil-contaminated possessions and the environment near Goi' and that at the time of instituting the suit, '[t]he oil has still not been fully cleaned up.' The plaintiffs attributed both spills to defective maintenance and failure by SPDC to replace its pipelines in a timely manner. ${ }^{47}$

The plaintiffs linked the particular facts of their case, the factual background in which it occurred and their legal claims by asserting that ' $[t]$ he oil spills that inflicted damage on plaintiff Dooh and the environment were not incidents; rather they were part of a pattern of oil spills as a result of Shell's oil production in the Niger Delta. ${ }^{48}$ Noting that the defendants were aware of the incidence of these spills and based on the pattern of oil spills in the Niger Delta, the plaintiffs contended that the defendants were under a stringent duty to act with due care to avoid the spills that are the subject of the instant litigation. ${ }^{49}$

\section{III.2 Expert and Judicial Opinions}

Interestingly, Netherlands is conspicuous for its absence in Halina Ward's often-quoted definition of foreign direct liability in the early part of this past decade. ${ }^{50}$ That these important cases were entertained and adjudicated upon in the Netherlands is an eloquent testimony to the expanding influence of foreign direct liability litigation and the emerging significance of the Netherlands as a key player in this odyssey. ${ }^{51}$ This article emphasises the core issues that the court focused on in disposing of the cases. The court addressed key procedural and substantive issues, namely standing and parent and subsidiary corporations' duty to prevent sabotage of oil installations. In reaching its decisions, the court relied in part on the opinions of a number of legal experts, including the present

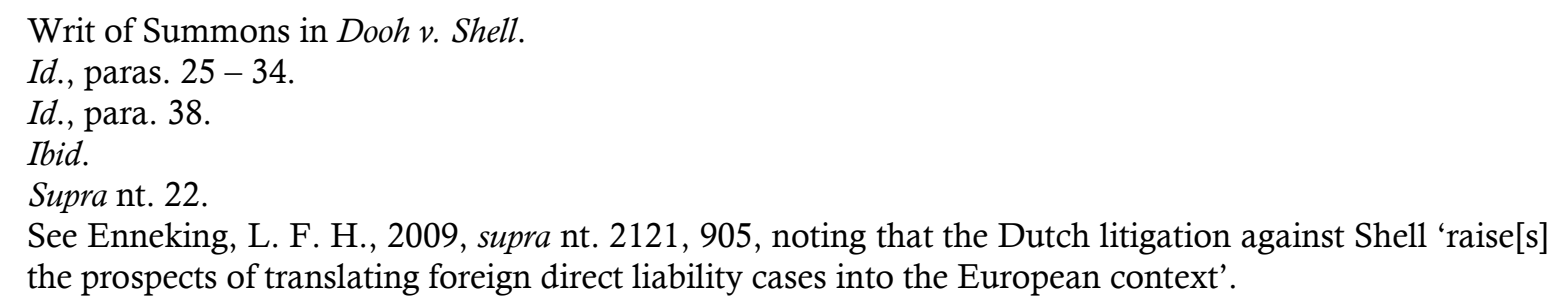


author, on aspects of Nigerian law. As relevant, references will be made periodically to portions of the opinions that are germane to this article.

Relying on the opinion of its expert, Professor Fidelis Oditah, QC, SAN, Shell argued that the plaintiffs lacked standing to commence or maintain the lawsuits because they did not have ownership or possession of the lands and fish ponds affected by the oil spill. Shell also argued that the plaintiffs could bring the action on behalf of their families or communities, whom Shell noted were the owners of the land, but in so doing the plaintiffs could not seek personal compensation but could only pursue collective recovery, which they were not doing. Moreover, there was no indication that they were authorised by the families or communities to bring the suits in a representative capacity. I concur with the view that either ownership or possession is a prerequisite for obtaining compensation for the spills under Nigerian law. I disagreed, however, that the plaintiffs had not shown that they were in possession. ${ }^{52}$ The court decided to focus only on the question of possession, since Shell had also conceded that proof of possession alone was sufficient to establish standing, contrary to its earlier insistence on both ownership and possession. ${ }^{53}$ The court found that the plaintiffs had established that they were in possession and thus entitled to bring the claims for compensation. ${ }^{54}$

The major substantive issue that demanded resolution was the plaintiffs' assertion that both the parent company and the Nigerian subsidiary owed a duty to prevent foreseeable sabotage of oil installations. Where such duty is not discharged and a third party vandalises oil facilities owned or controlled by a defendant, resulting in damage to a plaintiff, the plaintiff can maintain a claim in law against that defendant. The court held that a duty to prevent foreseeable sabotage exists under Nigerian law. Applying the rule to the facts, the court held that SPDC failed to discharge this duty in one of the cases (Akpan v. Shell) but not in the other two cases, as the facts of the latter did not provide a sufficient basis for SPDC's liability. ${ }^{55}$ In an unprecedented decision, the court held that 'SPDC had a specific duty of care in respect of the people living in the vicinity of the IBIBIO-I well and especially fishermen and farmers like Akpan, to take security measures against sabotage that can be reasonably demanded. ${ }^{56}$

In all three cases, the parent company was found not liable. In so holding, the Dutch court declined to apply the decision in the British case of Chandler v. Cape, in which the Court of Appeal in England held in 2012 that a parent company may be liable for the torts of its subsidiary abroad that caused harm to employees in the foreign country. ${ }^{57}$ The critical issue was that Chandler involved injury to employees, which is a smaller and more easily ascertainable class than the multitudes that could be affected by environmental misdeeds. Nevertheless, the Court was open to entertaining such cases where the victims of the environmental torts constitute a small group that has suffered an infraction of their property rights. The cases are currently on appeal and full analyses will await complete disposition and final determination on the issues. Yet, it is evident that litigation of this nature alone may not satisfy the quest for justice by many victims of environmental

\footnotetext{
52 I also argued that Shell's arguments against the plaintiff's ownership were flawed because they were based on inapplicable principles, such as quicquid plantatur solo, solo cedit.

53 Akpan v. Shell, supra nt. 43.

54 Ibid.

55 See Dooh v. Shell, supra nt. 44 and Oguru v. Shell, supra nt. 45.

56 Akpan v. Shell, supra nt. 43.

57 Court of Appeal, 25 April 2012, Chandler v. Cape, [2012] EWCA Civ. 525.
} 
pollution from oil spills in countries with weak legal protections. The next part argues that mandatory insurance may provide an additional arsenal in confronting environmental problems that arise from energy development in developing countries.

\section{Regulating Corporate Behavior through Liability Insurance}

Liability insurance exists in various areas of socio-economic activity, including vehicular accidents, workplace injuries, medical malpractice, legal malpractice, and director and officer responsibility. Insuring against damage to the environment is another important area in which insurance and insurance-like instruments have been utilized to address a major problem.

\section{IV.1 Preliminary Commentary}

The argument for insurance is premised on the notion that international tort litigation faces limitations as a tool for addressing environmental and human rights problems arising from operations of multinational corporations. These limitations include the length of time that resolving these disputes entails, the cost of litigation and procedural bottlenecks. Furthermore, foreign litigation options are only available to a small group of plaintiffs who are fortunate to find international non-governmental organizations that would embrace and finance their cause. An insurance scheme mandated by international law can help fill the gap. It is well known that under the international legal system there is little room for interference in the internal affairs of a country, with respect for a State's territorial integrity given preeminence. ${ }^{58}$ However, the progress made in the human rights area suggests an exception. International human rights and humanitarian law imposes responsibilities on States to guarantee certain rights or afford some level of protection to their citizens, when States are parties to the applicable treaties or when the obligations have become a part of customary international law. ${ }^{59}$ Protection from gross environmental abuse falls within the parameters of international human rights law.

There is an ongoing debate on whether to formulate a binding multilateral treaty through the United Nations Human Rights Council that holds corporations accountable for human rights violations. ${ }^{60}$ Any corporate human rights treaty agreed upon and adopted by the States should contain a provision that requires corporations to maintain a liability insurance policy that covers cases of catastrophic oil spills that cause massive environmental degradation in host communities. At present, such insurance policies are optional, at least among operators in Nigeria. ${ }^{61}$ The insurance proposal may also be extended to non-environmental areas, such as cases of torture involving corporate

58 The principle of non-intervention exists both in customary international law and under the United Nations Charter Article 2, para. 4; Kohen M., "The Principle of Non - Intervention 25 Years After the Nicaragua Judgment", Leiden Journal of International Law, vol. 25, ed. 01, 2012, 157.

59 See generally Hathaway O. A., et al., "Consent-Based Humanitarian Intervention: Giving Sovereign Responsibility Back to the Sovereign", Cornell International Law Journal, vol. 46, 2013, 499.

60 See e.g., Invitation from The Permanent Mission of Ecuador in Geneva to a workshop on Business and Human Rights on 11 and 12 of March, on file with author, 2014.

61 Email correspondence between the author's research assistant and an official of a state oil agency in Nigeria, on file with the author, 2013. 
complicity. The benefits of a mandatory insurance provision, which make the legal and economic case for insurance, are discussed below.

\section{IV.2 The Legal and Economic Case for Insurance}

Liability insurance is a veritable instrument for preventing harmful conduct and ensuring adequate compensation to the victims of dangerous activities within the scope of coverage. These two principal functions and other benefits of insurance are discussed below.

\section{IV.2.1. Preventing Harm}

Liability insurance aims to prevent a dangerous activity by imposing costs on the actors potentially responsible for the harmful acts. To contain the cost of insurance, the actors are expected to undertake their operations in a manner that would avoid liability and attendant payouts by the insurers. ${ }^{62}$ Moreover, the insurance companies have an incentive to avoid the occurrence of the insured event, as such savings redound to their financial benefit. Tom Baker and Rick Swedloff capture these points poignantly as follows:

Our focus, however, is at a step antecedent to litigation. Once insurers accept the financial responsibility for civil liability, they not only have an incentive to manage the defense and settlement of liability claims, but they also have an incentive to reduce the likelihood that those claims arise in the first place. This should make sense. Just as the fear of liability is supposed to incentivize potential wrongdoers to take appropriate precautions, fear of liability should incentivize an insurer to encourage its insured to take precautions. Once an insurer underwrites a risk, the insurer has every reason to try to reduce its payouts by encouraging insureds to prevent the potential loss from materializing. That can, and sometimes does, lead insurers to attempt to regulate loss-producing activities. ${ }^{63}$

This deterrence effect is evident in ship-source oil pollution, where novel and effective insurance arrangements in the oil pollution liability regime have had the incidental benefit of engendering deterrence with the overall result being a noticeable reduction of oil pollution incidents. ${ }^{64}$ There is empirical evidence that demonstrates that accidental oil spill incidents from tankers are experiencing a steady decline. ${ }^{65}$

62 See Yin, H., et al., "Risk-Based Pricing and Risk-Reducing Effort: Does the Private Insurance Market Reduce Environmental Accidents?", Journal of Law and Economics, vol. 54, 325, 326 2011, 325-326, stating that private insurance contracts can employ a system that rewards insured firms with premium discounts if they undertake risk-reducing activities.

63 Baker, T., and Swedloff, R., "Regulation by Liability Insurance: From Auto to Lawyers Professional Liability", UCLA Law Review, vol. 60, 2013, 1412, 1415, Citation omitted.

64 Billah, M. M., supra nt. 3, 73.

65 Id., 72-73. 


\section{IV.2.2. Regulatory Function}

Insurers' desire to prevent potential losses from manifesting leads them to take measures toward regulating the loss-producing activities. ${ }^{66}$ Viewed from this perspective, insurance provides a regulatory function. In societies with weak regulatory apparatuses, the importance of an additional, effective regulatory tool cannot be overemphasised. Indeed, as mentioned earlier, the foreign direct liability suits are instituted in foreign jurisdictions primarily because the domestic legal systems in the countries where the incidents took place do not provide effective remedies to the victims. Moreover, because insurance could avoid litigation, if every person involved plays their proper role, it also saves costs to the victims and provides a remedy to those victims of corporate tort liability that do not have the resources to litigate a claim domestically or in foreign jurisdictions.

\section{IV.2.3. Redressing Injury}

Insurance provides a guaranteed source of compensation for victims of the risky activity. Victims of pollution can bring tort claims against the oil companies responsible for the pollution. However, full recovery is not always assured, especially if the company has successfully kept its assets artificially low by dispersing them among different corporate entities scattered around the globe. ${ }^{67}$ The aim of compulsory insurance, therefore, is to make sure that adequate compensation is provided when certain unforeseeable accidents occur. ${ }^{68}$ To further ensure the effectiveness of this remedy, a mandatory insurance policy may incorporate a direct action component that entitles the victims to bring suit directly against the insurer. ${ }^{69}$

A direct action provision is valuable for a number of reasons. In some cases, pollution victims may be confronted with the unsavoury reality that the company responsible for the pollution is insolvent. ${ }^{70}$ With compulsory insurance, the victim may find comfort in the fact that the pollution is covered by the insurance policy maintained by the polluting company. Unfortunately, the insurance company would refuse to entertain the victims' claim for compensation under the insurance policy or deny any liability judgment obtained in court, asserting the absence of privity of contract between the insurer and the liability claimant. ${ }^{71}$ Additionally, the insurer may defeat the victims' claim by pleading available policy defences or exceptions, such as non-payment of premium, against the insured, which in turn affects the victim claiming through the insured. ${ }^{72}$ Providing for direct action eliminates these possibilities, as has been the case since its introduction under the ship-source oil pollution liability regime. ${ }^{73}$ Increased exposure to payouts to victims as a result of direct action propels insurers to charge higher premiums on

Baker, T., and Swedloff, R., supra nt. 63, 1415.

67 Billah, M. M., supra nt. 3, 52-53.

68 Id. 52 .

69 Id. 57: ' $\mathrm{t}]$ he object of ensuring adequate compensation to oil pollution victims is further strengthened by the provision of direct action against the insurer of a liable ship-owner. This is a major departure from traditional insurance policy under which a third party may not bring an action against the insurer because insurance is a contract between the insurer and the insured ship-owner. Therefore, there is no privity of contract between the insurer and a third party victim. This is especially the case in indemnity insurance as opposed to mere liability insurance.' (Citations omitted).

70 Id., 74.

71 Ibid.

72 Ibid.

73 Ibid. 
negligent ship-owners, which in turn induces the insured ship-owners to improve their standard of care to minimize the insurer's exposure to oil pollution claims. ${ }^{74}$ Indeed, because of direct action, insurers are further motivated to keep a watchful eye on the insured, resulting in heightened pressure on the insured to take optimal care in the conduct of its operations. ${ }^{75}$

Discussing maritime liability, one commentator makes a point that is germane to our discussion here by noting that 'adequate compensation through compulsory insurance and direct action may enhance the deterrence purpose of liability law. Without compulsory insurance and direct action, there is the possibility that a ship-owner may escape its liability, which may in turn lead the ship-owner to reduce its level of care. ${ }^{176}$ As already noted, victims' rights are also strengthened by excluding from the insurance regime, the ability of the insurer to use some defences that it could use against the insured, such as a failure to pay premiums. ${ }^{77}$

\section{IV.2.4. Monitoring Function}

Monitoring helps to discourage misconduct and encourage good behaviour. It is perhaps an incontrovertible fact that multinational corporate behaviour would be vastly improved with the presence of an effective monitoring system. Unfortunately, such a system hardly exists. Companies seem to favour internal monitoring and sometimes, under pressure, may resort to external monitoring by consultants that they select and compensate. Pure independent monitoring, while favoured by activists, is not readily embraced by business groups. Even in the case of independent monitoring, the independent monitor, which may be a non-governmental organization (NGO), may lack the commercial motivation to get to the root of the problem and ensure that it is adequately addressed. ${ }^{78}$ Insurance companies are in a unique position to fill these gaps. As commercial monitors, they can be catalysts of desired change and because their actions have financial implications for them and their shareholders, insurance companies have an incentive to act as effective monitors. ${ }^{79}$ When coupled with the direct action component discussed above, an insurer would be hard-pressed not to take this assignment seriously. Examples from the shipping industry provide an interesting basis for some measure of optimism. ${ }^{80}$

$74 \quad I d ., 74-75$.

Id., 75.

76 Id., 58 (Citation omitted).

77 Ibid.

78 An independent monitor could also be a court-appointed expert or required by a government agency as part of a settlement with a corporation under investigation. See Social Science Research Network, Root, V., "The Monitor-'Client' Relationship", January 15 2014, available online at $<$ papers.ssrn.com/sol3/papers.cfm?abstract_id $=2309498>$ (accessed April 14, 2014), providing a number of reasons for the retention of monitors to promote corporate compliance and the acceptance of the practice by corporations that are subject to enforcement actions; Warin, J. F., Diamant, M. S. and Root, V., "Somebody's Watching Me: FCPA Monitorships and How They Can Work Better", University of Pennsylvania Journal of Business Law, vol. 13, ed. 2, 2011, 321-381, 381: '[i]n situations that may call for an independent compliance monitor, all participants should seek to maximize the value of the monitorship and minimize inefficiency.'

79 In essence, they will be motivated by the fact that they have skin in the game.

80 See Billah, M. M., supra nt. 3, 74-75. 


\section{IV.2.5. Cascading Effect}

Insurance arrangements not only affect the behaviour of insurance companies and the insured persons paying the premiums. Changes in action could additionally spill over to those indirectly involved in terms of financial responsibility, but who nevertheless play an active role in the generation of the harmful incidents. This chain of actions and reactions would lead to better outcomes for potential victims. For instance, in the oil shipping area, where some of the compensation funds are funded by the oil industry and not by shipowners, oil companies have sought ways to protect their own interests by improving the behaviour of the shipping companies. ${ }^{81}$ One scholar describes the changes with the following words:

$[E] v e n$ though the second and third tier of insurance through the [Compensation Funds] are mainly designed for adequate compensation and are funded by the oil industry and not by ship-owners, these arrangements indirectly put pressure on ship-owners to be more diligent in the operation of their ships. This is because oil companies, who are the main contributors to both funds, are also the main, if not sole, customers of the oil-carrying ships (tankers). Given that the operation of these ships has a direct effect on the ultimate contributions that oil companies make to the Funds, oil companies as a group are naturally opposed to and united against substandard shipping. This opposition translates into various initiatives to motivate ship-owners toward optimal care. One such initiative is a database maintained by the oil industry on substandard ships, known as the Ship Inspection Report (SIRE) Program. The database contains inspection reports on many oil-carrying ships. ${ }^{82}$

In the case of human rights and environmental abuse, a regime of compulsory insurance could galvanise insurers and the insured to seek behaviour modification amongst government security agents and public policy makers that could lead to the introduction and implementation of policies and initiatives that protect both human rights and the environment.

\section{Potential Objections to Proposal}

A number of challenges threaten this proposal, posing as obstacles to its adoption or effective implementation. While these challenges are formidable, they are not insurmountable and should not be allowed to serve as permanent or perpetual impediments to the actualization of the desired objectives.

\section{V.1 Corporate Apathy}

One likely objection is that companies would most likely drop their environmental standards with the knowledge that somebody else would be responsible for paying the claims in the event of environmental mishaps. In essence, the proposal would protect bad

\footnotetext{
81 Id. 75-76.

82 Ibid. (citation omitted).
} 
behaviour and encourage the same vice that it is seeking to curtail. ${ }^{83}$ This moral hazard argument from the corporate standpoint has attracted the attention of experts in the field ${ }^{84} \mathrm{~A}$ valid counter-argument is that environmental liability insurance would promote the goal of environmental protection, as it would provide an incentive for insurers to only insure companies that are environmentally responsible. ${ }^{85}$ Companies that have been lax in implementing environmental reforms would also be motivated to raise their standards in order not to lose their insurability status and the negative implications of their ability to access the credit markets, among other possible consequences.

\section{V.2 Community Moral Hazard}

Another point of objection is the problem of a moral hazard on the part of the host community. It is not unheard of for an insurance beneficiary to orchestrate a turn of events that accelerate their opportunity for compensation under the insurance policy. Community members could create environmental disasters then turn in claims in order to be compensated. This is akin to a beneficiary of a life insurance policy who arranges for the death of the policy-holder so that they can get paid what the policy stipulates. Just as the beneficiary may suffer directly or indirectly for the death of the policy holder (e.g. emotionally) and yet is not deterred from carrying such act, some community members that would face the peril of environmental catastrophes may be similarly undeterred from such conduct by imagining the other benefits. This criticism should not, however, sound the death knell for the proposal. Insurers are expected to have strong underwriting and compensation standards that would help detect fraudulent conduct and claims tainted by fraud would obviously be excluded. Assuming that evidence indicating fraud is only uncovered after claims have been paid, the recipient community would be subject to harsh penalties. For instance, the insurers could cancel the policy upon discovery of the unacceptable behaviour, although the cancellation may be subject to arbitration. Another form of penalty may be to blacklist the communities that are involved and to additionally block companies investing in the blacklisted communities from having the requirements to maintain an insurance policy.

\section{V.3 Failure to Monitor}

The expectation that insurance companies would play the role of monitors effectively may be exaggerated or misplaced. For instance, some commentators note that in the case of "Director and Officer" insurance policies procured by companies for their managers, the insurance companies fail to monitor those insured adequately and may not even

83 A similar criticism has been levelled against a proposal for corruption and consumer risk insurance. See Okaru-Bisant, V., "Overcoming Challenges in The Multilateral Investment Guarantee Agency's Risk Insurance Coverage to Private Water Investors: Corruption and Consumer Risks", South Dakota Law Review, vol. 57, ed. 2, 2012, 277- 314, 291, stating that 'opponents of the corruption risk insurance propose a weak argument that providing corruption risk insurance coverage to private investors will encourage the vice and sanction bad behavior' (citation omitted).

84 Baker, T., and Swedloff, R., supra nt. 63, 1417-18 .

85 See Okaru-Bisant, V., supra nt. 83, 291, making a similar argument in relation to corruption risk insurance. 
engage in any monitoring activity ${ }^{86}$ However, this problem is unlikely to surface in the instance of the proposed insurance arrangement. Catastrophic oil spills present public relations problems that insurers would prefer to avoid, and effective monitoring both reduces the likelihood of occurrence and takes away a potential basis for blame by watchdog groups. The magnitude of the expected compensation in the case of catastrophic oil spills or gross human rights abuses makes it unlikely that any responsible insurance company would close its eyes to danger signals, as may be the case with smaller payouts for other types of insured activities. Additionally, with the direct action component, as the oil shipping sector has shown, insurance companies are likely to take their monitoring role seriously. ${ }^{87}$

\section{V.4 Unavailability of Insurance}

Unfortunately, even in advanced economies, insurance companies have not shown a huge appetite for environmental liability insurance. One prominent insurance law scholar addresses this point in the following words: 'Despite the demand for insurance coverage of pollution liability, however, such insurance is not generally offered [...]. In short, there is a mismatch between the losses resulting from oil spills, the insurance available to the victims of spills, the liability of the parties responsible for losses caused by spills, and the insurance available to the parties who face such liability. ${ }^{188}$ Insurers' reluctance to insure against pollution is traceable to a number of reasons. ${ }^{89}$ They include factual disputes engendered by the fact that some environmental injuries have a long latency period, ${ }^{90}$ leading to uncertainties about the policy years responsible for coverage, ${ }^{91}$ and the enormous cost of cleaning up pollution and remediating the affected areas. ${ }^{92}$ There is also the issue of the legal obstacles encountered in seeking to eliminate the moral hazard that would accompany insuring against gradually occurring pollution as opposed to sudden and accidental pollution. In the case of gradually occurring pollution, the insured companies can take steps to detect the pollution almost at inception and be in a position to mitigate the damage once they detect the pollution. ${ }^{93}$ With insurance, however, they would likely abandon this responsibility. Accordingly, to avoid the moral hazard, insurance companies have been willing to insure only sudden and accidental pollution, although judicial interpretation stymied this effort. ${ }^{94}$

In view of the limited availability of private environmental insurance, an alternative course should be explored. As is often the case where private options are not available, public options become desirable. One arrangement that offers a valuable template is insurance against political risks faced by companies doing business in some inclement

86 See Baer, M. H., "Book Review: Some Thoughts on the Porous Boundary between Ordinary and Extraordinary Corporate Fraud", University of Pennsylvania Journal of Business Law, vol. 14, ed. 4, 2012, 927-955, 929, discussing some authors' conclusions along those lines.

87 See Billah, M. M., supra nt. 3, 75-76.

88 Abraham, K. S., "Catastrophic Oil Spills and the Problem of Insurance", Vanderbilt Law Review, vol. 64, ed. 6, 2011, 1769-1791, $1769-1771$.

89 Id. 1784-1786.

$90 \quad$ Id. 1771 nt. 5.

91 Id. 1785-1786.

92 Id. 1786.

93 Id. 1784.

94 Id. 1784-1785. 
commercial environments. Through the Multilateral Investment Guarantee Agency (MIGA), companies are able to protect themselves against losses, thereby making it possible to venture into some unfavourable climes. ${ }^{95}$

MIGA, a part of the World Bank group, was established in the 1980s. ${ }^{96}$ The Convention Establishing the Multilateral Investment Guaranty Agency ${ }^{97}$ was concluded in 1985 and entered into force in $1988 .{ }^{98}$ Its stated mission is to "promote foreign direct investment (FDI) into developing countries to help support economic growth, reduce poverty, and improve people's lives.' ${ }^{99}$ MIGA concentrates on insuring investments in the areas where it believes it can make significant difference, notably in the world's poorest countries. For example these are countries that fall under the lending purview of the International Development Association, conflict-affected environments, complex deals in infrastructure and extractive industries; particularly those involving project finance and environmental and social considerations, and South-South investments (investments from one developing country to another). ${ }^{100}$

Foreign investors and host countries appreciate that the facilitation of foreign direct investment and the realization of its attendant benefits require a form of insurance against risk of loss. ${ }^{101}$ While investors may resort to the private insurance markets to protect themselves against commercial risks, they tend to look beyond their own abilities to address non-commercial risks, such as insecurity and abrupt political changes. ${ }^{102}$

95 Puig, S., "Emergence \& Dynamism in International Organizations: ICSID, Investor-State Arbitration \& International Investment Law", Georgetown Journal of International Law, vol. 44, 2013, 531 -- 560; Shihata, I. F. "The Settlement of Disputes Regarding Foreign Investment: The Role of the World Bank, with Particular Reference to ICSID and MIGA", American University Journal of International Law \& Policy, vol. 1, 1986, 97- 108.

96 The World Bank Group consists of five separate but related entities, namely the International Finance Corporation (IFC), Multilateral Investment Guarantee Agency (MIGA), International Bank for Reconstruction and Development (IBRD), International Development Association (IDA), and International Centre for Settlement of Investment Disputes (ICSID). See Puig, S., "Recasting ICSID's Legitimacy Debate: Towards a Goal-Based Empirical Agenda", Fordham International Law Journal, vol. 36, 2013, 465-466 nt. 1 and 489.

97 MIGA was created by the Convention Establishing the Multilateral Investment Guarantee Agency, opened for signature 11 October 1985, 24 I.L.M. 1598 (entered into force 12 April 1988); Convention Establishing the Multilateral Investment Guaranty Agency (MIGA), 1988, 1508 UNTS 99.) (Apr. 12, 1988), available online at <www.miga.org/documents/miga_convention_november_2010.pdf $\geq$ (accessed 24 April 2014).

98 Rowat, M. D., "Multilateral Approaches to Improving the Investment Climate of Developing Countries: The Cases of ICSID and MIGA", Harvard International Law Journal, vol. 33, 1992, 103, 105 and nt.9, 126.

99 Multilateral Investment Guarantee Agency, Overview, available online at <www.miga.org/whoweare/ index.cfm > (accessed 3 September 2013).

100 Ibid.

101 For a useful definition of risk and identification of several commercial and non-commercial risks, see Hoyos, J. C., "The Role of Bilateral Investment Treaties in Mitigating Project Finance's Risks: The Case of Colombia", Syracuse Journal of International Law and Commerce, vol. 40, 2013, 285-289; Comeaux, P. E. and Kinsella, N. S., "Reducing Political Risk in Developing Countries: Bilateral Investment Treaties, Stabilization Clauses, and MIGA \& OPIC Investment Insurance", New York Law School Journal of International and Comparative Law, vol. 15, 1994, 1-4. .

102 It should be noted that a private market for political risk insurance exists, although duration is usually shorter and the coverage limits smaller than those offered by public-based political risk insurance providers, such as the Overseas Private Investment Corporation (OPIC) and MIGA. See Van Detta, J. A, "Some Legal Considerations For E.U.-Based MNEs Contemplating High-Risk Foreign Direct 
Examining the role and growth of insurance for FDI, one writer observes: 'With respect to security, insurance instruments quickly adapted to the specific needs of countries and projects, to the point that insurance is now almost a prerequisite for investing in certain regions. The MIGA, an entity member of the World Bank offering insurance to foreign investors against losses caused by "non-commercial risks", is involved in virtually all big investment projects worldwide and has more than 170 member States . . . . ${ }^{103}$ Other commentators have further noted that an investor can minimize political risk by purchasing political risk insurance available from a number of sources, including nationally-sponsored insurance agencies, private insurers, and the World Bank's MIGA. This insurance typically provides coverage against risks such as currency inconvertibility, expropriation and similar measures, war and civil disturbance and breach of contract loss. ${ }^{104}$ An investor may purchase coverage for one of these risks or a combination thereof. ${ }^{105}$

MIGA exists to complement government-sponsored and private investment guarantee programs. ${ }^{106}$ Yet, in reality, MIGA is the preferred or sole option for some investors who may not qualify for national insurance programs because of their country of origin and who may lack the resources to pursue private insurance options with their limitations. ${ }^{107}$ Since inception, MIGA has insured about 600 projects, totalling billions of dollars in guarantees. ${ }^{108}$ MIGA appears to favour an approach that prevents claims filings by negotiating a resolution of disputes relating to its guaranteed investments. ${ }^{109}$ Accordingly, MIGA has only paid out for three claims over the years. ${ }^{110}$

A similar approach, in essence a MIGA-in-reverse, is needed to protect host communities from risks posed by the operations of the big companies that are within the purview of MIGA. The reverse-MIGA approach requires further elaboration in a separate work. Suffice it to say at this point, however, that while the potential merits of the approach are worth considering, such an approach is not without its limitations. For instance, it may be that MIGA is not properly equipped in terms of human and financial resources to undertake this task. It is believed that in the discharge of its current responsibilities, MIGA relies on the investors it is insuring to provide information about potential risk. ${ }^{111}$ A MIGA official reportedly attributes the agency's inability to visit local communities to conduct rigorous risk assessment to a lack of resources. ${ }^{112}$ One solution

Investments in the Energy Sector After Kiobel v. Royal Dutch Petroleum And Chevron Corporation v. Naranjo", South Carolina Journal of International Law and Business, vol. 9, 2013, 161.

103 Pereira, A., "Legal Stability Contracts in Colombia: An Appropriate Incentive for Investments? Historical Causes and Impact Analysis of Law 963 of 2005", Richmond Journal of Global Law and Business, vol. 12, 2013, 237-251.

104 Supra nt. 101, 32; MIGA Convention, Art. 11.

105 See generally, supra nt. 99.

106 Supra nt. 101, 40.

107 Id. 40; Supra nt. 98, 126.

108 Halabi, S. F., "Efficient Contracting Between Foreign Investors and Host States: Evidence from Stabilization Clauses", Northwestern Journal International Law and Business, vol. 31, 2011, 261 - 275.

109 Id. 276. See also supra nt. 95, 115.

110 Supra nt. 108, $275-276$.

111 Supra nt. 111, 292, proposing a system that ensure that MIGA would 'reduce its main reliance on the information that it receives from its private guarantee holders prior to issuing risk insurance coverage to them'.

112 Id., 291, nt. 76. 
may be to create an entirely new agency, outside of, or as an adjunct to, any of the existing major international institutions, such as the United Nations.

\section{Conclusion}

The topic of the social, economic and environmental costs of foreign investment is one that continues to deserve national and international attention. Lawsuits have been filed against international companies seeking to develop the vast energy resources in some developing countries. The latest iteration of this litigation battles is being played out in European courts, including cases brought by three sets of Nigerian plaintiffs against Shell Petroleum. This article has analyzed the relevance of these lawsuits in getting redress for private victims of energy development as well as in promoting the general cause of environmental protection. It argues that litigation, while valuable, is only a limited tool whose effectiveness can be strengthened by deploying other tools. One such tool proposed in this article is a regime of compulsory international insurance for catastrophic oil spills or other massive environmental harms, occurring within the territory of countries hosting the energy development activities. Insurance will, among other things, provide redress for victims and deter unpalatable conduct on the part of the energy companies.

Ultimately, the enduring solution is for international corporations to do the right thing, which includes eliminating double standards by conducting operations the way they would in their home countries. ${ }^{113}$ Corporations can move in that direction without the backing or mandate of legislation. Without question, virtually any corporation would proceed with any reasonable measures it calculates would enhance its primary purpose of generating profit. Perhaps, the society could facilitate the desired change by properly rewarding companies that take the plunge.

\section{www.grojil.com}

113 Supra nt. 42, 244. 